\title{
KAJIAN STRUKTUR ARANG DARI LIGNIN ${ }^{1)}$ (Study on Charcoal Structure of Lignin)
}

\author{
Oleh/By : \\ Gustan Pari $^{2)}$, Kurnia Sofyan ${ }^{3)}$, Wasrin Syafii ${ }^{3)}$, Buchari ${ }^{4)}$ \& Hiroyuki Yamamoto ${ }^{5)}$
}

\begin{abstract}
This paper discusses charcoal structure of lignin at different temperature of carbonization. The charcoal was produced in a stainless steel retort with electrical heater at temperatures of 200,300,400,500,650,750, and $850^{\circ} \mathrm{C}$. Chemical structure evaluation was undertaken using Fourier Transform Infra Red (FTIR), X-Ray Diffraction (XRD) and Scanning Electron Microscope (SEM). Results of XRD showed that the interlayer spacing of aromatic sheets (d) and width of aromatic layers $(\mathrm{La})$ decreased with increasing carbonization temperature, height of aromatic layers $(\mathrm{Lc})$, the degree of crystalinity $(X)$ and the average number $(N)$ of aromatic layers rose with increasing carbonization temperature. The FTIR spectra of charcoal showed that heat treatment of lignin in the range of $300-750^{\circ} \mathrm{C}$ produced the most significant changes in chemical stucture. The bonds of $\mathrm{O}-\mathrm{H}$, and $\mathrm{C}=\mathrm{C}$ decreased with increasing carbonization temperature, while the other stuctures increased first in the chars and then developed aromatic structure. At temperature of $850^{\circ} \mathrm{C}$ the charcoal possessed $\mathrm{C}-\mathrm{H}$ alifatics, $\mathrm{C}=\mathrm{O}$ and $\mathrm{C}-\mathrm{O}-\mathrm{C}$ bonds from aromatic structure. The analysis of SEM showed that the amount and the diameter of the pore enlarged as the temperature increased. Good quality charcoal was reached at the carbonization temperature of $500^{\circ} \mathrm{C}$. The produced charcoal has degree of crystalinity $33.90 \%$, height of aromatic layes $(\mathrm{Lc}) 3.21 \mathrm{~nm}$, width of aromatic layers (La) $10.96 \mathrm{~nm}$, number of aromatics layers (N) 8,67 and distance of aromatic layers $d\left({ }_{002}\right)=0.35 \mathrm{~nm}$ and $d\left({ }_{100}\right)=0.21 \mathrm{~nm}$ with pore diameter of $12.60 \mu \mathrm{m}$. This charcoal had higher crystalinity, polarity, rigidity, hardness and largerpore.
\end{abstract}

Keywords: charcoal, diffraction, lignin, chemical structure.

\begin{abstract}
ABSTRAK
Tulisan ini membahas struktur arang dari lignin pada suhu karbonisasi yang berbeda. Proses pembuatan arang lignin dilakukan pada suhu $200,300,400,500,650,750$ dan $850^{\circ} \mathrm{C}$ dalam suatu retort yang terbuat dari baja tahan karat yang dilengkapi dengan pemanas listrik Untuk mengetahui perubahan struktur arang yang terjadi dilakukan analisis dengan menggunakan FTIR, XRD dan SEM. Hasil

\footnotetext{
${ }^{1)}$ Naskah ini merupakan bagian dari disertasi doktor dan kerjasama JSPS Core University Program

${ }^{2)}$ Pusat Litbang Hasil Hutan, Bogor

${ }^{3)}$ Departemen Teknologi Hasil Hutan IPB, Bogor

(4) Departemen Kimia ITB, Bandung

${ }^{5)}$ Lab of Biomaterial Physic, Nagoya University, Jepang
} 
analisis XRD menunjukkan bahwa jarak antar ruang lapisan aromatik (d) dan lebar lapisan aromatik (La) menurun dengan makin meningkatnya suhu karbonisasi, sedangkan untuk tinggi lapisan aromatik (Lc), derajat kristalinitas $(\mathrm{X})$ dan jumlah lapisan aromatik $(\mathrm{N})$ meningkat dengan makin naiknya suhu karbonisasi. Spektrum FTIR dari arang lignin menunjukkan bahwa antara suhu $300-500^{\circ} \mathrm{C}$ terjadi perubahan struktur kimia dari bahan baku secara nyata. Ikatan $\mathrm{OH}$, dan $\mathrm{C}=\mathrm{C}$ alifatik menurun dengan naiknya suhu, sedangkan struktur eter dan aromatik makin berkembang. Pada suhu $850^{\circ} \mathrm{C}$ arang yang dihasilkan mempunyai struktur aromatik yang permukaannya mempunyai gugus $\mathrm{C}-\mathrm{O}-\mathrm{C}, \mathrm{C}=\mathrm{O}$ dan $\mathrm{C}-$ H. Analisis SEM menunjukkan bahwa jumlah dan diameter pori arang meningkat dengan makin naiknya suhu karbonisasi. Kualitas arang yang baik diperoleh pada suhu karbonisasi $500^{\circ} \mathrm{C}$ yang menghasilkan derajat kristalinitas sebesar 33,90 \%, tinggi lapisan aromatik $3.21 \mathrm{~nm}$, lebar lapisan aromatik $10,96 \mathrm{~nm}$, jumlah lapisan aromatik 8,67 , jarak antar lapisan aromatik $\mathrm{d}_{(002)}=0,35 \mathrm{~nm}$ dan $\left.\mathrm{d}_{(100)}\right)$ $=0,21 \mathrm{~nm}$ dengan diameter pori arang antara 12,6 $\mu \mathrm{m}$. Arang ini mempunyai sifat keteraturan yang tertinggi, permukaannya bersifat polar, kaku, keras dan struktur porinya makropori.

Kata kunci: Arang, difraksi, lignin, struktur kimia.

\section{PENDAHULUAN}

Lignin merupakan komponen kimia utama yang terdapat dalam kayu selain selulosa dan hemiselulosa yang berfungsi sebagai perekat di dalam dinding sel, dan sebagai unsur struktural dari pohon serta tanaman berlignoselulosa lainnya. Susunan unsur utama lignin adalah unit fenilpropana yang saling berhubungan melalui ikatan eter membentuk suatu polimer yang bercabang dengan struktur tiga dimensi (Achmadi, 1990). Kandungan karbon dalam lignin cukup tinggi yaitu sebesar 60-65 \% untuk kayu daun jarum dan sebesar 56-60\% untuk kayu daun lebar (Fengel dan Wegener, 1995).

Banyak penelitian mengenai arang dan arang aktif, namun belum diketahui peran komponen utamanya, yaitu selulosa dan lignin dalam hal pembentukan kristalit arang dari atom karbon. Demikian pula bagaimana perubahan pola struktur kayu sampai menjadi arang dan arang aktif. Padahal pemahaman yang lebih luas dan mendalam mengenai pola struktur tersebut sangat penting sebagai dasar pembuatan arang dan turunannya yang berkualitas tinggi, dapat diaplikasikan secara luas serta memberikan nilai manfaat yang lebih besar.

Perkembangan penelitian arang dan arang aktif menunjukkan bahwa lignin yang di isolasi dengan asam asetat (acetic acid lignin) dapat dikonversi lebih lanjut manjadi serat arang dan serat arang aktif (Kubo et al., 2003). Brandl et al. (2004) mengemukakan bahwa komposit polimer dari serat karbon yang dalam pembuatannya dicampur dengan polypropilen, dapat digunakan sebagai komponen struktural mobil dan kapal terbang karena ringan dan sifat daya hantar listriknya dapat diatur. Selain itu serat karbon yang dikarbonisasi pada suhu $550-700^{\circ} \mathrm{C}$ mempunyai sifat grafitik yang besar sehingga dapat berfungsi sebagai bahan anoda dan dapat digunakan untuk pembuatan batere lithium (Yoon et al., 2004).

Dalam penelitian ini dilakukan pirolisa lignin pada berbagai tingkatan suhu karbonisasi dengan tujuan untuk mengetahui mekanisme perubahan struktur dan sifat arang dari lignin. 


\section{BAHAN DAN METODE}

\section{A. Bahan}

Bahan baku yang digunakan adalah Lignotech yaitu lignin yang di isolasi dari larutan bekas pemasak pulp dengan proses kraft yang diperoleh dari Norwegia. Bahan kimia yang digunakan adalah kalium bromida (KBr.). Proses karbonisasi dilakukan di Laboratorium Kimia Pusat Litbang Hasil Hutan, Bogor. Pengujian FTIR dilakukan di ITB, Bandung. Sedangkan pengujian XRD dan SEM dilakukan di Nagoya University, Jepang. Kegiatan penelitian ini dilakukan pada tahun 2003.

\section{B. Metode}

1. Pembuatan arang

Arang dibuat di dalam suatu tungku yang terbuat dari baja tahan karat yang dilengkapi dengan pemanas listrik dan termokopel. Pengarangan dilakukan dengan cara memanaskan lignin pada suhu $200,300,400,500,650,750$ dan $850^{\circ} \mathrm{C}$ masing-masing selama 5 jam.

\section{Identifikasi struktur arang}

Untuk mengetahui perubahan struktur yang terjadi selama proses karbonisasi dilakukan analisis gugus fungsi menggunakan Spektrofotometri Infra Merah (IR) tipe Pelkin Elmer 1600 dengan tujuan untuk mengetahui perubahan gugus fungsi arang lignin sebagai akibat dari perubahan suhu karbonisasi. Topografi permukaan arang aktif dengan Scanning Electron Microscope (SEM) tipe Hitachi 4500, yang dilakukan dengan cara melapis bahan baku dengan platina, dengan tujuan untuk mengetahui topografi permukaan arang. Untuk mengetahui derajat kristalin (X), jarak antar lapisan (d), tinggi (Lc) dan lebar (La) antar lapisan aromatik serta jumlah $(\mathrm{N})$ lapisan aromatik digunakan difraksi sinar X (XRD) dengan tipe Shimadzu, XD-DI dengan sumber radiasi tembaga (Iguchi, 1997; Jimenez et al., 1999; Kercher, 2003) dan tujuannya adalah untuk mengetahui struktur kristalit arang lignin.

Derajat kristalinitas $(\mathrm{X})$ ditentukan dengan rumus di bawah ini:

$$
\mathrm{X}=\frac{\text { Bagian kristal x } 100 \%}{\text { Bagian kristal }+ \text { Bagian amorf }}
$$

Selanjutnya beberapa sifat fisiko-kimia arang ditentukan berdasarkan persamaan-persamaan berikut ini:

Jarak antar lapisan aromatik $\left(\mathrm{d}_{002}\right): \lambda=2 \mathrm{~d} \sin \theta$

Tinggi lapisan aromatik $\left(\mathrm{L}_{c}\right): \mathrm{L}_{\mathrm{c}(002)}=\mathrm{K} \lambda / \beta \cos \theta$

Lebar lapisan aromatik $\left(\mathrm{L}_{\mathrm{a}}\right): \mathrm{L}_{\mathrm{a}(100)}=\mathrm{K} \lambda / \beta \cos \theta$

Jumlah lapisan aromatik $(\mathrm{N}): \mathrm{N}=\mathrm{L}_{\mathrm{c}} / \mathrm{d}$

Di mana $: \lambda=0,15406 \mathrm{~nm}$ (panjang gelombang dari radiasi sinar $\mathrm{Cu}$ ), $\beta=$ Intensitas $1 / 2$ tinggi dan lebar $(\operatorname{radian} \theta), K=$ Tetapan untuk lembaran graphene $(0,89), \theta=$ Sudut difraksi. 


\section{HASIL DAN PEMBAHASAN}

\section{A. Identifikasi Gugus Fungsi}

Hasil analisis dengan spektrofotometer inframerah disajikan pada Tabel 1 dan Gambar 1. Pola spektrum FTIR dari lignin yang tidak dikarbonisasi menunjukkan adanya vibrasi gugus hidroksil karena terdapat serapan di daerah bilangan gelombang $3423 \mathrm{~cm}^{-1}$ dengan posisi pita serapan gugus $\mathrm{OH}$ yang terikat. Adanya serapan pada bilangan gelombang $2919 \mathrm{~cm}^{-1}$ (2931 $2837 \mathrm{~cm}^{-1}$ ) menunjukkan adanya vibrasi C-H dari C-H alifatik. Hal ini diperkuat dengan adanya pita serapan di daerah $1454 \mathrm{~cm}^{-1}$. Pita serapan pada bilangan gelombang 1596-1508 $\mathrm{cm}^{-1}$ menunjukkan adanya vibrasi $\mathrm{C}=\mathrm{C}$ dari senyawa aromatik. Pita serapan di daerah bilangan gelombang $1211 \mathrm{~cm}^{-1}$ menunjukkan adanya vibrasi C-O-C dari struktur eter yang mempunyai 6 cincin, sedangkan pita serapan pada bilangan gelombang $1043 \mathrm{~cm}^{-1}$ menunjukkan adanya vibrasi $\mathrm{C}-\mathrm{O}$ dari $\mathrm{C}-\mathrm{OH}$ primer.

Tabel 1. Bilangan gelombang imframerah lignin

Table 1. Wave number of lignin infrared

\begin{tabular}{|c|c|}
\hline $\begin{array}{c}\text { Suhu } \\
\text { (Temperature) }{ }^{0} \mathrm{C}\end{array}$ & $\begin{array}{c}\text { Bilangan gelombang } \\
\text { (Wave number) }, \mathrm{cm}^{-1}\end{array}$ \\
\hline 25 & $3423-2931-1596-1508-1454-1396-1211-1043$ \\
200 & $2931-2837-1593-1511-1460-1208-1043$ \\
300 & $3154-1631-1560-1396-1196-1108-1049$ \\
400 & $3142-1731-1584-1448-1131-873-837$ \\
500 & $3154-1725-1584-1443-1131-873$ \\
650 & $3148-1731-1460-1166-1114-843$ \\
750 & $3101-2978-1778-1443-1119-879$ \\
850 & $2860-1778-1431-1155-879$ \\
\hline
\end{tabular}

Hasil analisis spektrofotometri inframerah (Gambar 1) menunjukkan bahwa selama proses karbonisasi pada lignin terjadi penguraian struktur kimia yang mirip dengan pola spektrum karbonisasi selulosa (Pari, 2004). Perlakuan panas pada karbonisasi lignin mengakibatkan perubahan gugus fungsi. Pemanasan pada suhu $400-850^{\circ} \mathrm{C}$ mengakibatkan terbentuknya gugus karbonil yang ditunjukkan oleh adanya pita serapan pada daerah bilangan gelombang $1731-1778 \mathrm{~cm}^{-1}$. Selain itu tidak nampak adanya vibrasi dari $\mathrm{C}=\mathrm{C}$ aromatik yang ditunjukkan oleh tidak adanya pita serapan di daerah bilangan gelombang $1584 \mathrm{~cm}^{-1}$. Namun demikian teridentifikasi adanya vibrasi $\mathrm{C}-\mathrm{H}$ dari senyawa aromatik karena terdapat serapan di daerah bilangan gelombang $3154 \mathrm{~cm}^{-1}$ yang diperkuat dengan adanya serapan di daerah bilangan gelombang $879 \mathrm{~cm}^{-1}$. Pola ini berbeda dengan karbonisasi selulosa, di mana pemanasan pada suhu $400^{\circ} \mathrm{C}$ sudah terjadi penurunan intensitas di daerah bilangan gelombang $3400-1900 \mathrm{~cm}^{-1}$. Hal ini menunjukkan bahwa perlakuan panas pada proses karbonisasi mengakibatkan perubahan gugus fungsi yang diikuti dengan penataan kembali atom karbon. Pola spektrum ini sesuai dengan yang dikemukakan oleh Menendez et al. (1999); 


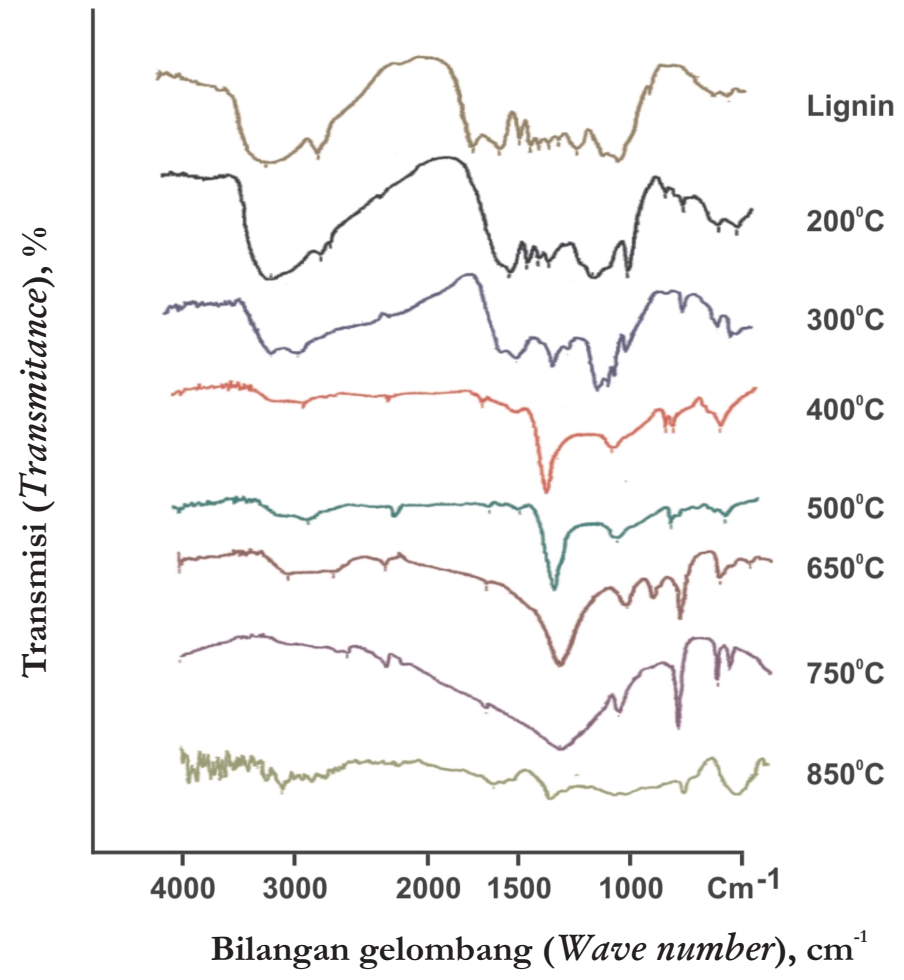

Gambar 1. Spektrum FTIR lignin

Figure 1. Spectrum of lignin FTIR

Ercin dan Yurum (2003) serta Kimura et al. (2004) yang menyimpulkan bahwa menurunnya intensitas serapan di daerah bilangan gelombang $3000-2700 \mathrm{~cm}^{-1}$ akan meningkatkan terbentuknya senyawa aromatik dari atom karbon.

Berdasarkan data di atas dapat dikemukakan bahwa struktur lignin yang dikarbonisasi pada suhu $400-750^{\circ} \mathrm{C}$ tidak memiliki gugus fungsi $\mathrm{OH}$, dan ada indikasi terjadinya perubahan gugus fungsi $\mathrm{C}=\mathrm{C}$ aromatik, sedangkan lignin yang dikarbonisasi pada suhu $850^{\circ} \mathrm{C}$ menunjukkan adanya vibrasi $\mathrm{C}-\mathrm{H}, \mathrm{C}=\mathrm{O}$, dan $\mathrm{C}-\mathrm{O}-\mathrm{C}$ dari senyawa aromatik. Adanya gugus fungsi tersebut yang menempel pada permukaan arang, maka arang yang dihasilkan bersifat polar.

\section{B. Identifikasi Pola Struktur Kristalit Lignin}

Difraktrogram dari XRD (Tabel 2) menunjukkan pola serupa dengan pola XRD pada selulosa dalam hal jarak lapisan antar kristalit yang berbentuk aromatik (d) yang makin sempit dengan meningkatnya suhu karbonisasi dari $200-850^{\circ} \mathrm{C}$ (Pari, 2004).

Pada awal pemanasan $\left(200^{\circ} \mathrm{C}\right)$ ada indikasi daerah amorf dari bahan baku terdegradasi membentuk struktur yang lebih kristalin $\theta$ 22,5, dan selanjutnya meningkat dengan naiknya 
suhu karbonisasi (Tabel 2) disertai dengan terbentuknya struktur kristalit baru, yang ditunjukkan oleh munculnya intensitas baru di daerah $\theta 26$ dan 43 (Gambar 2). Hasil ini sesuai dengan penelitian terdahulu yang mengemukakan bahwa pada suhu karbonisasi $300^{\circ} \mathrm{C}$ struktur asli yang terdapat di dalam lignin hilang, yang berarti terjadi dekomposisi lignin yang disusul dengan terbentuknya struktur kristalit baru pada daerah $\theta 26$ dan 43 (Huang dan Saka, 2003).

Peningkatan derajat kristalinitas terus meningkat sampai suhu karbonisasi $500^{\circ} \mathrm{C}$, dengan tetap didominasi struktur amorf. Hal ini dikarenakan struktur dasar lignin bersifat amorf. Sifat amorf lignin ini menyulitkan dalam pembuatan struktur arang, karena meskipun dipanaskan sampai suhu $3000^{\circ} \mathrm{C}$ strukturnya tetap amorf padahal pola struktur arang yang ideal pada umumnya mengandung derajat kristalinitas yang relatif besar (Ota dan Mozammel 2003). Tabel 2 dan Gambar 2 juga menunjukkan bahwa tinggi lapisan (Lc) antar susunan kristalit dalam arang lignin semakin menurun dengan naiknya suhu karbonisasi. Fenomena ini menggambarkan adanya pengerutan ikatan antar atom karbon dalam lignin sehingga jarak (d) antar lapisan aromatik bertambah pendek, dan jumlah $(\mathrm{N})$ lapisan berkurang, serta lebar (La) lapisan aromatiknya melebar, sehingga terjadi kerusakan pada pola struktur arang lignin. Atas dasar ini maka arang yang dihasilkan bersifat kaku. Fenomena ini tidak jauh berbeda dengan yang diungkapkan oleh Byrne dan Nagle (1997) serta Lopez et al. (2000).

Tabel 2. Derajat kristalin (X), jarak antar lapisan aromatik (d), tinggi dan lebar (Lc \& La) antar lapisan aromatik serta jumlah lapisan $(\mathrm{N})$ aromatis pada lignin

Table 2. Degree of crystalinity (X), distance of aromatic layers (d), beight and width (Lc E La) of aromatic layers and number of aromatic layers $(N)$ of lignin

\begin{tabular}{|c|c|c|c|c|c|c|c|c|}
\hline $\begin{array}{c}\text { Suhu } \\
(\text { Temperature }), \\
\mathrm{OC}\end{array}$ & $\begin{array}{c}\mathrm{X} \\
(\%)\end{array}$ & $\begin{array}{c}\theta \\
\left({ }^{\mathrm{O}}\right)\end{array}$ & $\begin{array}{c}\mathrm{d} \\
(\mathrm{nm})\end{array}$ & $\begin{array}{c}\theta \\
\left(^{\mathrm{O}}\right)\end{array}$ & $\begin{array}{c}\mathrm{d} \\
(\mathrm{nm})\end{array}$ & $\begin{array}{c}\mathrm{L}_{\mathrm{c}} \\
(\mathrm{nm})\end{array}$ & $\mathrm{N}$ & $\begin{array}{c}\mathrm{L}_{\mathrm{a}} \\
(\mathrm{nm})\end{array}$ \\
\hline 25 & 4,3 & - & - & - & - & - & - & - \\
200 & 6,7 & $(22,5)$ & 0,3947 & - & - & - & - & - \\
300 & 19,2 & $(23,4)$ & 0,3797 & - & - & 4,0105 & 10,64 & - \\
400 & 23,2 & $(23,8)$ & 0,3734 & - & - & 3,3608 & 9,32 & - \\
500 & 33,9 & $(24,0)$ & 0,3703 & $(43,0)$ & 0,2101 & 3,2119 & 8,67 & 10,96 \\
650 & 29,0 & $(25,8)$ & 0,3449 & $(43,0)$ & 0,2101 & 2,4790 & 7,18 & 11,25 \\
750 & 28,3 & $(26,0)$ & 0,3423 & $(43,0)$ & 0,2101 & 2,3030 & 6,70 & 11,63 \\
850 & 24,5 & $(26,0)$ & 0,3423 & $(43,0)$ & 0,2101 & 1,7913 & 5,23 & 17,45 \\
\hline
\end{tabular}




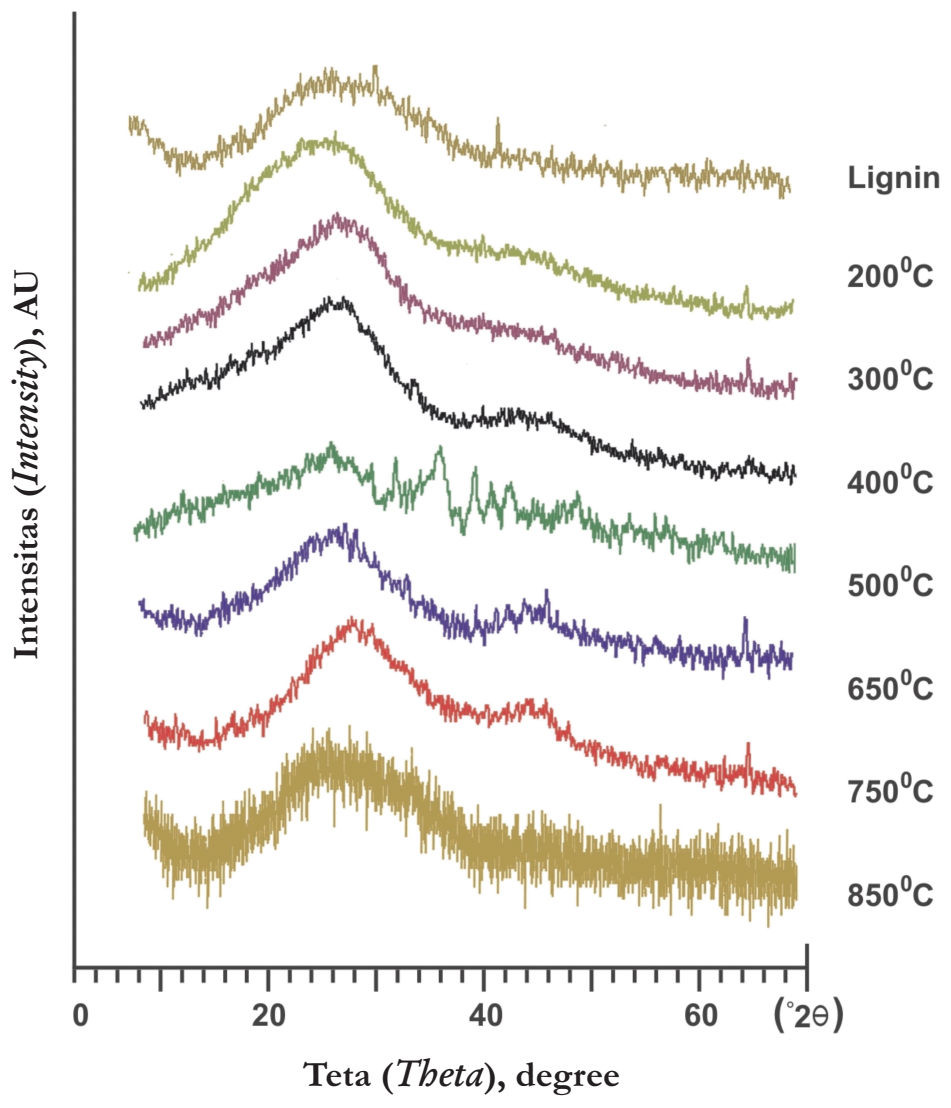

Gambar 2. Difraktogram XRD lignin

Figure 2. Difractogram of lignin XRD

Berdasarkan data di atas dapat dikemukakan bahwa peningkatan suhu dalam proses karbonisasi lignin mengakibatkan terjadinya pergeseran antar lapisan kristalit dalam lignin dan mengubah struktur amorfnya sehingga terbentuk pola struktur baru yang berbeda dengan asalnya sebagaimana dilukiskan pada Gambar 3 dan arangnya lebih bersifat kaku dan keras. 


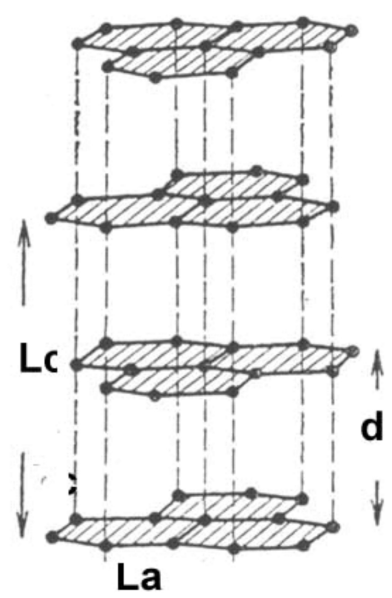

Gambar 3. Skema tinggi lapisan (Lc), jumlah lapisan (N) dan lebar lapisan (La) aromatik struktur kristalit arang

Figure 3. Scheme of height $(\mathrm{Lc})$, number $(\mathrm{N})$ and width (La) of aromatic layers of charcoal crystalyte structure

Sumber (Source): Schukin et al. (2002)

\section{Identifikasi Pola Struktur Pori Lignin}

Hasil analisis mikrofotograf SEM menunjukkan bahwa pada lignin yang tidak dikarbonisasi secara fisik serupa dengan selulosa, yaitu tidak menunjukkan adanya pori (Gambar 4), demikian pula dengan karbonisasi ligninnya pada suhu yang sama. Akibat meningkatnya suhu karbonisasi, selain meningkatkan diameter pori arangnya menjadi lebih besar (Tabel 3) juga mengakibatkan kerusakan pada dinding pori sehingga arangnya lebih bersifat makropori. Hal ini dimulai pada suhu $300^{\circ} \mathrm{C}$, di mana dinding pori yang kecil bergabung dengan pori lain membentuk pori yang lebih besar (Hayashi et al., 2002). Ukuran pori tersebut termasuk ke dalam struktur makropori karena lebih dari 0,025 $\mu \mathrm{m}$ (Beukens et al., 1985). 


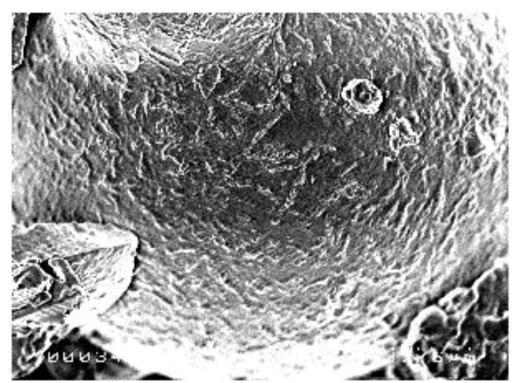

Lignin

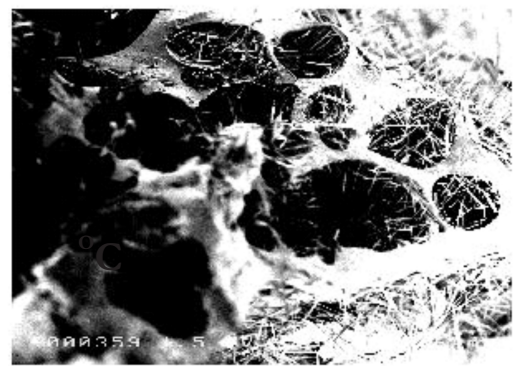

$300^{\circ} \mathrm{C}$

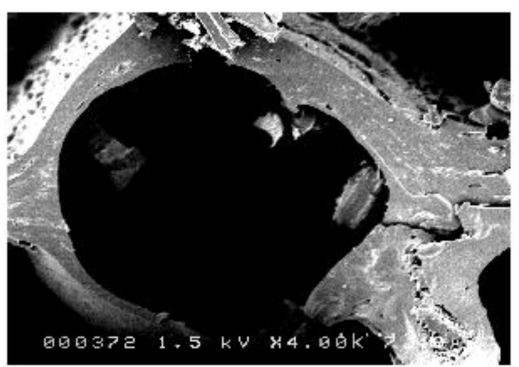

$500^{\circ} \mathrm{C}$

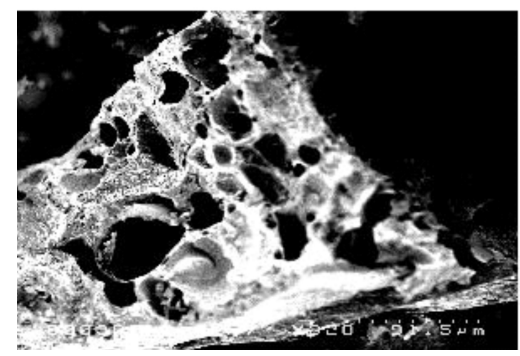

$750^{\circ} \mathrm{C}$

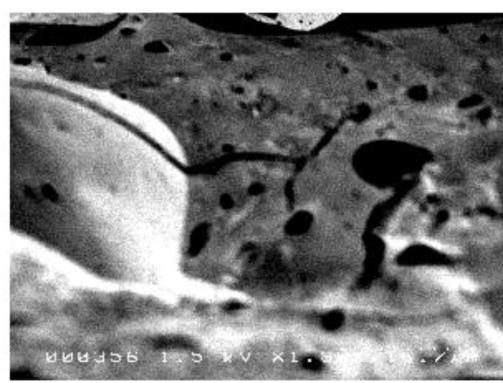

$200^{\circ} \mathrm{C}$

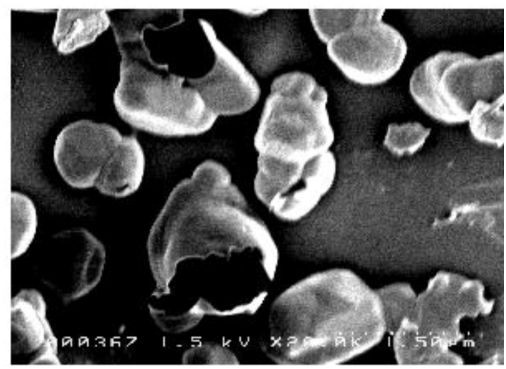

$400^{\circ} \mathrm{C}$

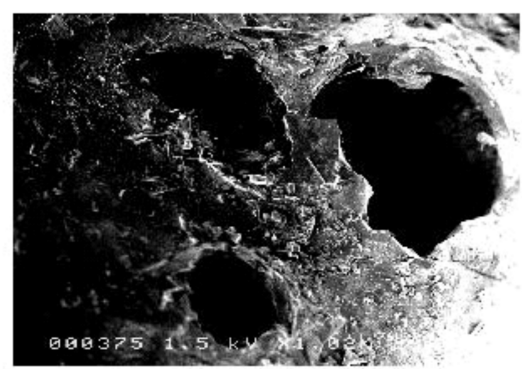

$650^{\circ} \mathrm{C}$

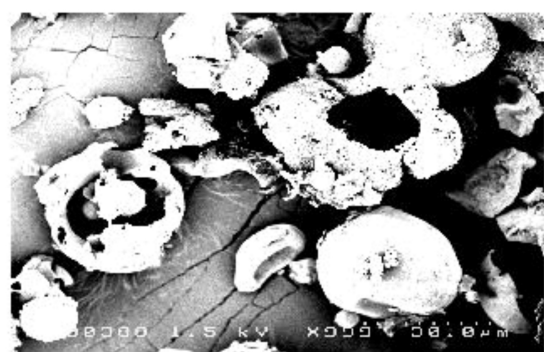

$850^{\circ} \mathrm{C}$

Gambar 4. Topografi permukaan arang lignin

Figure 4. Surface topograph of lignin charcoal 
Berdasarkan pola topografi permukaan yang disajikan pada Gambar 4 diduga bahwa pori arang lignin yang terbentuk berasal dari adanya penguapan komponen lignin yang terdegradasi, seperti yang disinyalir oleh Novicio, et al. (1998) yang mengemukakan bahwa proses terbentuknya pori diakibatkan oleh menguapnya zat terbang dari bahan baku akibat proses karbonisasi (Gambar 5). Dengan demikian karbonisasi pada lignin mengubah pola struktur permukaannya menjadi pola baru yang berbeda dengan asalnya. Bila dikaitkan dengan ukuran pori yang terbentuk ada kemungkinan bahwa semakin lebar dan banyaknya diameter pori dengan meningkatnya suhu karbonisasi, semakin banyak pula jumlah komponen lignin terdegradasi yang menguap. Penguapan bahan-bahan tersebut mengakibatkan pergeseran antara lapisan kristalit dalam lignin dan mengubah struktur kristalitnya sehingga terbentuk kristal baru yang berbeda dengan struktur asalnya sebagaimana terlihat pada hasil identifikasi pola struktur dengan XRD (Gambar 2). Namun demikian adanya sejumlah produk dekomposisi lignin yang menguap ini akan menguntungkan, karena bila tidak demikian produk tersebut akan mengisi atau menutup celah di antara lembaran aromatik arang (Villegas dan Valle, 2001), sehingga daya adsorpsi arang menurun.

Tabel 3. Diameter pori permukaan arang hasil karbonisasi Table 3. Pore diameter at charcoal surface after carbonization

\begin{tabular}{|c|c|}
\hline $\begin{array}{c}\text { Suhu } \\
\text { (Temperature), }{ }^{\circ} \mathrm{C}\end{array}$ & $\begin{array}{c}\text { Diameter lignin } \\
\text { (Lignin diameter), } \mu \mathrm{m}\end{array}$ \\
\hline 200 & $0,4-0,6$ \\
300 & $0,7-0,8$ \\
400 & $0,7-0,9$ \\
500 & 12,6 \\
650 & $12-15$ \\
750 & $9,0-18$ \\
850 & $15-18$ \\
\hline
\end{tabular}
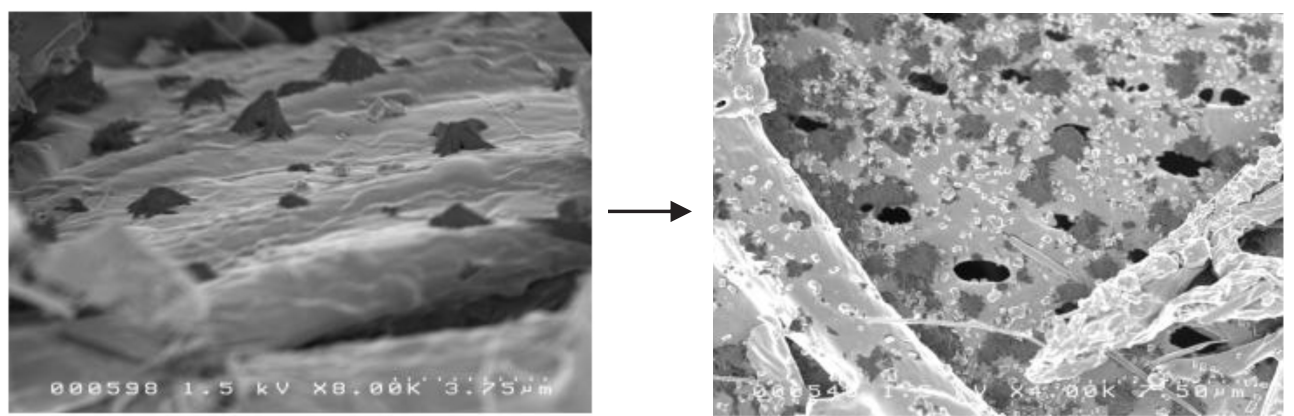

Gambar 5. Proses pembentukan pori arang

Figure 5. Process of charcoal pore formation 


\section{KESIMPULAN}

1. Perlakuan panas pada proses karbonisasi lignin memutus ikatan gugus fungsi membentuk radikal tidak stabil, dan permukaan arang mengandung ikatan $\mathrm{C}-\mathrm{O}-\mathrm{C}, \mathrm{C}=\mathrm{O}$ dan $\mathrm{C}-\mathrm{H}$ dari senyawa aromatik, maka sifat arangnya menjadi polar

2. Peningkatan derajat kristalinitas arang sampai suhu $500^{\circ} \mathrm{C}$ diikuti dengan meningkatnya tinggi dan jumlah lapisan susunan aromatik, dan selanjutnya derajat kristalinitas menurun sampai suhu $850^{\circ} \mathrm{C}$. Penurunan derajat kristalinitas arang ini diikuti dengan melebarnya lapisan aromatik dan tinggi lapisan aromatiknya bertambah pendek, sehingga sifat arangnya menjadi kaku dan keras.

3. Struktur arang yang baik diperoleh pada suhu karbonisasi $500^{\circ} \mathrm{C}$ memiliki derajat kristalinitas sebesar 33,9\%, tinggi lapisan aromatik 3,21 nm, lebar lapisan aromatik 10,96 $\mathrm{nm}$, jumlah lapisan aromatik 8,67, jarak antar lapisan aromarik $\mathrm{d}_{(\mathrm{oo2})}=0,3557 \mathrm{~nm}$ dan $\mathrm{d}_{(100)}$ $=0,2101 \mathrm{~nm}$ dan diameter pori arang antara 12,6 $\mu \mathrm{m}$ dan arangnya bersifat makropori.

\section{DAFTAR PUSTAKA}

Achmadi, S. 1990. Kimia kayu. Departemen Pendidikan dan Kebudayaan Direktorat Jenderal Pendidikan Tinggi. Pusat Antar Universitas Ilmu Hayat. Institut Pertanian Bogor.

Byrne, C.E. and D.C. Nagle. 1997. Carbonized wood monolits-characterization. Carbon. 35 (2): 267-273. Elsevier, UK.

Brandl, W., G. Marginean., V. Chirila, and W. Warschewski. 2004. Production and characterisation of vapour grown carbon Fiber/polypropylene composites. Carbon. 42 : 5-9. Elsevier, UK.

Buekens, A., Keirsse, H., Schoeters, J and A. Verbeeck. 1985. Production of activated carbon from Euphorbia Tiraculli, Vrije Universiteit Brussel.

Ercin, D. and Y. Yurum. 2003. Carbonisation of fir (Abies bornmulleriana) wood in an open pyrolysis system at 50 3000C. J Anal and Appl Pyrol. 67:11-22. Elsevier, UK.

Fengel, D. and G. Wegener. 1995. Kayu: kimia, ultrastruktur, reaksi-reaksi. Gadjah Mada University Press, Yogyakarta.

Hayashi, J., T. Horikawa., I. Takeda., K. Muroyama, and F.N. Ani. 2002. Preparing activated carbon from various nutshells by chemical activation with K2CO3. Carbon 40: 23812386. Elsevier, UK.

Huang, B. and S. Saka. 2003. Photocatalytic activity of TiO2 Crystallite-activated carbon composites prepared in supercritical isopropanol for the decomposition of formaldehyde. J. Wood Science. 49(1): 79-85, The Japan Wood Research Society. Japan.

Iguchi M. 1997. Practice of polymer X-ray diffraction (Short-course textbook). Bandung Institute of Technology, Bandung. 
Jimenez, A. Iglesias M.J. Defarge F.L. and I.S. Ruiz. 1999. Effect of the increase in temperature on the evolution of the physical and chemical structure of vitrinite. J Anal and Appl Pyrol . 50: 117-148. Elsevier, UK.

Kercher, A. and D.C. Nagle. 2003. Microstructural evolution during charcoal carbonization by X-ray diffraction analysis. Carbon 41: 15-27. Elsevier, UK.

Kimura, Y. Sato, T. and C. Kaito. 2004. Production and structural characterization of carbon soot with narrow UV absorption feature. Carbon. 42: 33-38. Elsevier, UK.

Kubo, S., Uraki, Y and Y. Sano. Caralytic graphitization of hardwood acetic acid lignin with nickel acetate. J. Wood Science. 49 (2): 188-192, The Japan Wood Research Society. Japan.

Lopez, M.C.B., A.M. Alonso, and J.M.D. Tascon. 2000. N2 and CO2 adsorption on activated carbon fibers prepared from nomex chars. Carbon 38: 1177-1182. Elsevier, UK.

Menendez, J.A. Menendez E.M. Iglesias M.J. Garcia A. and J.J. Pis. 1999. Modification of the surface shemistry of active carbons by means of microwave induced treatments. Carbon. 37: 1115-1121. Elsevier, UK.

Novicio, L.P. Hata T. Kajimoto T. Imamura Y. and S. Ishihara. 1998. Removal of mercury from aqueous solutions of mercuric chloride using wood powder carbonized at high temperature. J. Wood Research. No 85: 48-55, The Japan Wood Research Society. Japan.

Ota, M. and H. M. Mozammel (2003). Chemical kinetics of Japanese cedar, cypress, fir and spruce and characterization of charcoal. J. Wood Science. 49 (1): 248-254. The Japan Wood Research Society. Japan.

Pari, G. (2004). Kajian struktur arang aktif dari serbuk gergaji sebagai adsorben emisi formaldehida dengan logis. Disertasi sekolah Pascasarjana. Institut Pertanian Bogor, Bogor.

Schukin, L.I., Kornnievich M.V. Vartapetjan R.S. and S.I. Beznisko. 2002. Low temperature plasma oxidation of activated carbons. Carbon. 40:2021-2040. Elsevier, UK.

Villegas, J.P. and C.J.D Valle (2001). Pore structure of chars and activated carbons prepared using carbon dioxide at different temperatures from extracted rockrose. Carbon 57: 113. Elsevier, UK.

Yoon, S.H., C.W. Park., H. Yang., Y. Korai., I. Mochida., R.T.K. Baker and N.M. Rodriguez. 2004. Novel carbon nanofibers of high graphitization as anodic materials for lithium ion secondary batteries. Carbon 42: 21-32. Elsevier, UK. 